\title{
HONORARIUM
}

\section{The 2014 recipient of the Brady Medal: Professor David J. Siveter}

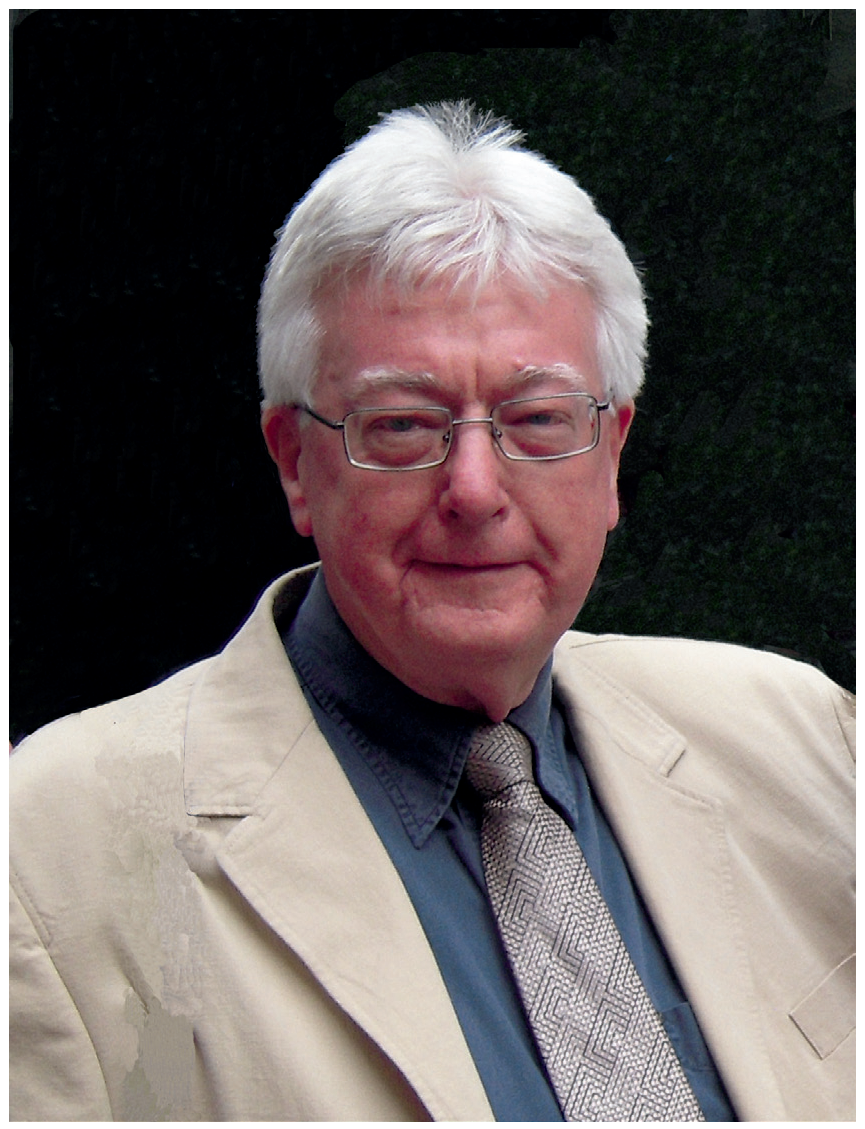

During his time as Chair of The Micropalaeontological Society (2004-7) David Siveter was an innovative leader and, amongst other things, introduced the term President, which of course benefited his successor, and, most importantly, his was the inspiration to propose a senior medal for the TMS, the Brady Medal. The medal was named in honour of the Brady brothers, G.S. Brady and H.B. Brady, who were distinguished early workers with ostracods and foraminifera, respectively. It was David Siveter's idea that the Brady Medal should not simply be a piece of bronze but also a work of art in its own right, as indeed it is; the background is described in Siveter $(2008 a)$. It is therefore particularly satisfying that the eighth Brady Medal be awarded to David Siveter in recognition of his fundamental contributions to our understanding of life in the Palaeozoic.

It is not possible to write about David Siveter without passing reference to his twin brother Derek as the Siveter twins have had parallel careers in many ways and both are distinguished Palaeozoic palaeontologists, David with bivalved crustaceans and Derek with arthropods. The Siveter twins were born in
Wolverhampton, then Staffordshire, in 1946 and early on developed a love of sport and the outdoors, perhaps as a subconscious counterpoint to the heavily industrialized, urban environment of the 'Black Country'. Sunday outings with their parents to especially Shropshire inspired a love of that rugged landscape and in due course an interest in the Ordovician and Silurian rocks and their abundant fossils. On wet Sundays Mr and Mrs Siveter would drop the boys at Birmingham Museum and Art Gallery where the natural history collection, although small, helped to foster an interest in the natural world and, coincidentally, an interest in art as now reflected in the Brady Medal itself. There then arose the opportunity to study O-level and A-level Geology at school, taught by an enthusiastic Aberystwyth graduate Alan Beasley, and additionally through secondment to Wolverhampton Technical College where soft-rock and palaeontology courses were taught by Peter Toghill. Field excursions to the Wren's Nest and Walsall Silurian inliers, both replete with macro- and microfossils, reinforced a particular fascination with the lower end of the geological column. The decision for David and Derek to study Geology at university was by now a natural path and both joined the University of Leicester where they fell under the inspiring tuition and charismatic personality of Professor Peter Colley Sylvester-Bradley.

Sylvester-Bradley was a man of wide-ranging interests but had started his research life working on ostracods (although never completing his $\mathrm{PhD}$ ). His suggestion to David of a $\mathrm{PhD}$ programme on Silurian ostracods fitted well with the latter's interests and it was a field in urgent need of attention, there having been little work since the pioneering days of T.R. Jones in the nineteenth century. David set to and became an expert in preparing silicon casts (Siveter, 1982; a technique essentially used in macropalaeontology and which he developed to provide high-fidelity results for microfossils), revising the tangled taxonomy with the aid of the scanning electron microscope (SEM) and stereo-pair images, and gained his $\mathrm{PhD}$ in 1974. He remained at Leicester as a Post-Doctoral Fellow and helped Sylvester-Bradley launch $A$ Stereo-Atlas of Ostracod Shells, which was designed to take advantage of the powers of the recently developed SEM, Sylvester-Bradley having achieved a coup by securing the second ever SEM off the Cambridge Instruments production line. Although declining subscriptions forced closure of the StereoAtlas in 1999 it is still a valuable archive of images, and David Siveter was Senior Editor and a frequent contributor for its entire history. Appointment as a Lecturer in Leicester followed, with promotion to Reader, Professor and, in 2011, Emeritus Professor of Palaeontology. David has thus very unusually spent his entire academic career in one institution.

The $\mathrm{PhD}$ and early research years were dominated by the need to revise the taxonomy of, especially, Silurian ostracods but a hint of widening interests and indeed of what was to come in the future was in the publication of 'Habitats and modes of life of 
Silurian ostracods' (Siveter, 1984) and 'Ostracods across the Iapetus Ocean' (Schallreuter \& Siveter, 1985). While taxonomic work continued, it was as a necessary tool leading to better understanding of the temporal and spatial distributions of mid-Palaeozoic ostracods. In the early 1990s David and research student Mark Williams turned their attention to the enigmatic Cambrian bivalved crustacean bradoriid and phosphatocopid groups, widely believed to be the Cambrian representatives of the Ostracoda (Williams et al., 1994; Siveter et al., 1995, 1996; Siveter \& Williams, 1997). The bradoriids led them to the early Cambrian Chenjiang Lagerstätte of Yunnan Province in China where careful comparison of the preserved appendages of the bradoriid Kunmingella with those of modern ostracods demonstrated conclusively that it was not an ostracod, indeed not even a crustacean (Hou et al., 1996). Finding rare fossilized soft-parts requires a certain amount of good luck, but David did not leave everything to chance and the discovery of a phosphatocopid specimen with three-dimensionally preserved appendages in Shropshire was the result of a carefully planned and targeted excavation of Lower Cambrian limestones in a deliberate search for such material (Siveter et al., 2001, 2003b). Such exciting finds confirmed that neither the bradoriids nor the phosphatocopids were ancestral ostracods, but represented other groups of small, bivalved arthropods. This begged the questions: where were the early Palaeozoic ostracods with soft-part preservation, and did the Ostracoda have any pre-Ordovician fossil record?

At this point a dramatic discovery was made, a Silurian volcaniclastic deposit in Herefordshire with nodules containing softbodied fossils (Briggs et al., 1996). The problem was that while the fossils could be seen in two dimensions on the split surfaces of the nodules, there was no way to extract them intact. It became clear that the only way to study the material was by the method of serial-grinding, using digital images captured at intervals of $20-30 \mu \mathrm{m}$ to make a virtual fossil, which could then be viewed in the round on the computer screen, and in 3D (Sutton et al., 2001a), and thereafter the technology of Virtual Palaeontology developed (e.g. Sutton et al., 2012). The results have been truly spectacular for a wide variety of major fossil groups, including, for instance, arthropods (e.g. sea spiders, Siveter et al., 2004; barnacles, Briggs et al., 2005), molluscs (Sutton et al., 2001b, 2004) and polychaetes (Sutton et al., 2001c). The discovery of ostracods with soft-parts has yielded perhaps the most impressive results, certainly with respect to the ethos of this society (Siveter et al., $2003 a, 2007,2010$ ) - including sexual dimorphism and brood care in the Silurian and then in the Ordovician (Siveter et al., 2014). All of the ostracods found in Herefordshire so far turn out to be members of the living nekto-benthonic myodocope group, some with appendage characteristics remarkably close to the living forms, but with a range of carapace bauplan. This latter discovery provides not only important information for evolutionary biology but is also a warning to workers who necessarily rely only on carapace characteristics to identify and classify fossil material, especially from the Palaeozoic (Siveter, et al., 2013). We were tempted from the beginning of this paragraph to write 'ostracods' because it has become clear that many early bivalved arthropods such as bradoriids are not ostracods, although in the past they have been claimed to be, and the systematic position of the Palaeocopida, the most diverse group of Palaeozoic 'ostracods', remains unclear (Siveter, 2008b). Finally, David Siveter and colleagues with experience with Palaeozoic fossils have had to educate themselves in the soft-part biology of a range of living animals, a particularly challenging task with regard to crustaceans and their appendage homologies.

While the results of work on the Herefordshire Lagerstätte might seem to be the highpoint of David Siveter's career, a range of other research themes is evident. As alluded to above, these include an interest in the Lower Palaeozoic faunas of China which was longstanding (his first visit was in 1986 before this became fashionable), most notably the spectacular Chengjiang fossils (e.g. Hou et al., 2004: the first book in English on the biota), his contribution to winning UNESCO World Heritage status for the site, and in related exceptionally preserved fossils (Zhang et al., 2007). Then there is work on visual systems (e.g. Tanaka et al., 2009, 2014), colonization of the marine water column by benthos (e.g. Perrier et al., in review), and colonization of continental nonmarine waters (e.g. Bennett et al., 2012). There is no sign of this exceptional productivity waning, a second edition of the Chengjiang book is on its way, and we look forward to further seminal contributions from David Siveter, a thoroughly deserving recipient of the Brady Medal.

\section{ACKNOWLEDGEMENTS}

We are indebted to Professors Derek J. Siveter (Oxford) and Mark Williams (Leicester) for advice and information.

\section{REFERENCES}

Bennett, C., Siveter, D.J., Davies, S.J., Williams, M., Wilkinson, I.P., Browne, M. \& Miller, C.G. 2012. Ostracods from freshwater and brackish environments of the Carboniferous of the Midland Valley of Scotland: The early colonisation of terrestrial water bodies. Geological Magazine, 149: 366-396.

Briggs, D.E.G., Siveter, D.J. \& Siveter, D.J. 1996. Soft-bodied fossils from a Silurian volcaniclastic deposit. Nature, 382: 248-250.

Briggs, D.E.G., Sutton, M.D., Siveter, D.J. \& Siveter, D.J. 2005. Metamorphosis in a Silurian Barnacle. Proceedings of the Royal Society London B, 272: 2365-2369.

Hou, X.-G., Siveter, D.J., Williams, M., Walossek, D. \& Bergström, J. 1996. Preserved appendages in the arthropod Kunmingella from the early Cambrian of China: Its bearing on the systematic position of the Bradoriida and the fossil record of the Ostracoda. Philosophical Transactions of the Royal Society B, 351: 1131-1145.

Hou, X.-G., Aldridge, R.J., Bergström, J., Siveter, D.J., Siveter, D.J. \& Feng, X.-H. 2004. The Cambrian Fossils of Chengjiang, China. The Flowering of Early Animal Life. Blackwell, Oxford, 233pp.

Perrier, V., Williams, M. \& Siveter, D.J. in review. Origins, fossil record and ecological significance of marine arthropod zooplankton. Earth Science Reviews.

Schallreuter, R.E.L. \& Siveter, D.J. 1985. Ostracodes across the Iapetus Ocean. Palaeontology, 28: 577-598.

Siveter, D.J. 1982. Casts illustrating fine ornament of a Silurian Ostracod. In: Bate, R.H., Robinson, E. \& Sheppard, L.M. (eds) Fossil and Recent Ostracods. British Micropalaeontological Society, 105-122.

Siveter, D.J. 1984. Habitats and modes of life of Silurian ostracods. In: Bassett, M.G. \& Lawson, J.D. (eds) The Autecology of Silurian Organisms. Special Papers in Palaeontology, 32: 71-85.

Siveter, D.J. 2008a. The Brady Medal. Journal of Micropalaeontology, 27: 1-4, http://doi.org/10.1144/jm.27.1.1

Siveter, D.J. 2008b. Ostracods in the Palaeozoic? Senckenbergiana Lethaea, 88: 1-9. 
Siveter, D.J. \& Williams, M. 1997. Cambrian bradoriid and phosphatocopid arthropods of North America. Special Papers in Palaeontology, 57: 1-69.

Siveter, D.J., Rushton, A.W.A. \& Siveter, D.J. 1995. An ostracod-like arthropod with appendages preserved from the lower Ordovician of England. Lethaia, 28: 299-307.

Siveter, D.J., Williams, M., Peel, J. \& Siveter, D.J. 1996. Bradoriids (Arthropoda) from the early Cambrian of North Greenland. Transactions of the Royal Society of Edinburgh: Earth Sciences, 86: 113-121.

Siveter, D.J., Williams, M. \& Waloszek, D. 2001. A phosphatocopid crustacean from the lower Cambrian of England. Science, 293: 479-481.

Siveter, D.J., Sutton, M.D., Briggs, D.E.G. \& Siveter, D.J. 2003a. An Ostracode crustacean with soft parts from the Lower Silurian. Science, 300: 1749-1751.

Siveter, D.J., Walozsek, D. \& Williams, M. 2003b. An early Cambrian phosphatocopid crustacean with three-dimensionally preserved soft-parts from Shropshire, England. Special Papers in Palaeontology, 70: 9-30.

Siveter, D.J., Sutton, M.D., Briggs, D.E.G. \& Siveter, D.J. 2004. A Silurian sea spider. Nature, 431: 978-980.

Siveter, D.J., Siveterd, D. J., Sutton, M.D. \& Briggs, D.E.G. 2007. Brood care in a Silurian ostracod. Proceedings of the Royal Society of London B, 274: 465-469.

Siveter, D.J., Briggs, D.E.G., Siveter, D.J. \& Sutton, M.D. 2010. An exceptionally preserved myodocopid ostracod from the Silurian of Herefordshire, UK. Proceedings of the Royal Society of London B, 277: 1539-1544, http://doi.org/10.1098/rspb.2009.2122

Siveter, D.J., Briggs, D.E.G., Siveter, D.J., Sutton, M.D. \& Joomun, S.C. 2013. A Silurian myodocope with preserved soft-parts: Cautioning the interpretation of the shell-based ostracod record. Proceedings of the Royal Society of London B, 280: http://doi.org/10.1098/rspb.2012.2664

Siveter, D.J., Tanaka, G., Farrell, C.Ú., Martin, M.J., Siveter, D.J. \& Briggs, D.E.G. 2014. Exceptionally preserved 450 million-year-old Ordovician ostracods with brood care. Current Biology, 24: 801-806.

Sutton, M., Briggs, D.E.G., Siveter, D.J. \& Siveter, D.J. $2001 a$. Methodologies for the visualization and reconstruction of threedimensional fossils from the Silurian Herefordshire Lagerstätte. Palaeontologia Electronica, 4: 17.

Sutton, M.D., Briggs, D.E.G., Siveter, D.J. \& Siveter, D.J. 2001b. An exceptionally preserved vermiform mollusc from the Silurian of England. Nature, 410: 461-463.

Sutton, M., Briggs, D.E.G., Siveter, D.J. \& Siveter, D.J. 2001c. A 3D preserved polychaete from the Silurian of Herefordshire. Proceedings of the Royal Society of London B, 268: 2355-2363.

Sutton, M.D., Briggs, D.E.G., Siveter, D.J. \& Siveter, D.J. 2004. Computer reconstruction and analysis of the vermiform mollusc Acaenoplax hayae from the Herefordshire Lagerstätte (Silurian, England), and implications for molluscan phylogeny. Palaeontology, 47: 293-318.

Sutton, M.D., Garwood, R.J., Siveter, D.J. \& Siveter, D.J. 2012. SPIERS and VAXML: A software toolkit for tomographic visualisation, and a format for virtual specimen exchange. Palaeontologica Electronica, 15: 14.

Tanaka, G., Siveter, D.J. \& Parker, A.R. 2009. The visual system and paleoecology of the Silurian ostracod Primitiopsis planifrons. Journal of Paleontology, 83: 414-421.

Tanaka, G., Parker, A.R. et al. 2014 Mineralised rods and cones suggest colour vision in a $300 \mathrm{Myr}-\mathrm{old}$ fossil fish. Nature Communications, 5: 5920, http://doi.org/10.1038/ncomms6920.

Williams, M., Siveter, D.J., Rushton, A.W.A. \& Berg-Madsen, V. 1994. The Upper Cambrian bradoriid ostracod Cyclotron lapworthi is a hesslandonid. Transactions of the Royal Society of Edinburgh: Earth Sciences, 85: 123-130.

Zhang, X.-G., Siveter, D.J., Waloszek, D. \& Maas, A. 2007. An epipoditebearing crown-group crustacean from the Lower Cambrian. Nature, 449: 595-598.

\section{David J. Horne}

School of Geography,

Queen Mary University of London,

Mile End Road,

London E1 4NS, UK and

Department of Zoology,

The Natural History Museum

Cromwell Road,

London SW7 5BD, UK

\section{Alan Lord}

Senckenberg Forschungsinstitut, Senckenberganlage 25, D-60325 Frankfurt-am-Main, Germany (e-mail: Alan.Lord@senckenberg.de) 
